\title{
JURNAL PENELITIAN KEPERAWATAN
}

\section{Volume 4, №. 2, Agustus 2018}

Studi Fenomenologi: Kehidupan Masyarakat Paska Erupsi Gunung Kelud Tahun 2014

Hubungan Mekanisme Cedera dan Trauma Organ Lain dengan Prognosis Pasien Cedera Kepala Berat

Kandungan Fitokimia dan Zat Gizi Pada Formulasi Es Krim Jamu Kunyit Asam

Peran Manajer Keperawatan Dalam Menciptakan Motivasi Kerja Perawat

Perkembangan Motorik Anak Usia Prasekolah di Posyandu Balita Mawar dan Kenanga

Kompres Hangat Dan Relaksasi Nafas Dalam Efektif Menurunkan Nyeri Pasien Reumatoid Artritis

Pengetahuan Pasien Pre Operasi dalam Persiapan Pembedahan

Adaptasi Psikologis Ibu Postpartum (Fase Taking- In)

Motivasi Penatalaksanaan Empat Pilar Diabetes Mellituspada Pasien dengan Diabetes Mellitus

Pelatihan Penangganan Korban Tersedak Terhadap Pemahaman Tujuan, Prosedur, Kewaspadaan, dan Evaluasi Tindakan

Diterbitkan oleh

STIKES RS. BAPTIS KEDIRI

\begin{tabular}{|c|c|c|c|c|c|}
\hline $\begin{array}{c}\text { Jurnal Penelitian } \\
\text { Keperawatan }\end{array}$ & Vol.4 & No.2 & $\begin{array}{c}\text { Hal } \\
88-187\end{array}$ & $\begin{array}{c}\text { Kediri } \\
\text { Agustus 2018 }\end{array}$ & 2407-7232 \\
\hline
\end{tabular}




\section{JURNAL PENELITIAN KEPERAWATAN}

Volume 4, No. 2, Agustus 2018

Penanggung Jawab

Aries Wahyuningsih, S.Kep., Ns., M.Kes

Ketua Penyunting

Srinalesti Mahanani, S.Kep., Ns., M.Kep

Sekretaris

Desi Natalia Trijayanti Idris, S.Kep., Ns., M.Kep

\section{Bedahara}

Dewi Ika Sari H.P., SST., M.Kes

Penyunting Ahli:

Dr. Titih Huriah, S.Kep., Ns., M.Kep., Sp.Kom

Penyunting Pelaksana

Aries Wahyuningsih, S.Kep., Ns., M.Kes

Tri Sulistyarini, A.Per Pen., M.Kes

Dewi Ika Sari H.P., SST., M.Kes

Erlin Kurnia, S.Kep., Ns., M.Kes

Dian Prawesti, S.Kep., Ns., M.Kep

Maria Anita Yusiana, S.Kep., Ns., M.Kes

Sirkulasi

Heru Suwardianto, S.Kep., Ns M.Kep

Diterbitkan Oleh:

STIKES RS. Baptis Kediri

Jl. Mayjend Panjaitan No. 3B Kediri

Email: uuptppmstikesbaptis@gmail.com

Link: http://jurnalbaptis.hezekiahteam.com/jurnal 


\title{
JURNAL PENELITIAN KEPERAWATAN
}

\author{
Volume 4, №. 2, Agustus 2018
}

\section{DAFTAR ISI}

Studi Fenomenologi: Kehidupan Masyarakat Paska Erupsi Gunung Kelud Tahun 2014

\section{Lilik Setiawan}

Hubungan Mekanisme Cedera dan Trauma Organ Lain dengan Prognosis Pasien 101-109 Cedera Kepala Berat

Nurul Fatwati Fitriana

Kandungan Fitokimia dan Zat Gizi Pada Formulasi Es Krim Jamu Kunyit Asam Nurul Hidayah

Peran Manajer Keperawatan Dalam Menciptakan Motivasi Kerja Perawat

Paramita Pasthikarini I Aries Wahyuningsih I Selvia David Richard

Perkembangan Motorik Anak Usia Prasekolah di Posyandu Balita Mawar dan Kenanga

Yul Siskawati I Dewi Ika Sari Hari Poernomo I Srinalesti Mahanani

Kompres Hangat Dan Relaksasi Nafas Dalam Efektif Menurunkan Nyeri Pasien Reumatoid Artritis

Dimas Alfana Bouries Doliarn'do I Sandy Kurniajati I Erva Elli Kristanti

Pengetahuan Pasien Pre Operasi dalam Persiapan Pembedahan

Andika Kurniawan I Erlin Kurnia I Akde Triyoga

Adaptasi Psikologis Ibu Postpartum (Fase Taking- In)

Ni Komang Gita Rasmi I Maria Anita Yusiana I Dian Taviyanda

Motivasi Penatalaksanaan Empat Pilar Diabetes Mellituspada Pasien dengan 168-177 Diabetes Mellitus

Nataliel Dwi Prayoga I Tri Sulistyarini I Erva Elli Kristanti

Pelatihan Penangganan Korban Tersedak Terhadap Pemahaman Tujuan, 178-187 Prosedur, Kewaspadaan, dan Evaluasi Tindakan

Heru Suwardianto I Erawati 


\title{
PERKEMBANGAN MOTORIK ANAK USIA PRASEKOLAH DI POSYANDU BALITA MAWAR DAN KENANGA
}

\author{
PRESCHOOL CHILDREN MOTORIC DEVELOPMENT AT POSYANDU \\ BALITA MAWAR AND KENANGA
}

\author{
Yul Siskawati, Dewi Ika Sari Hari Poernomo, Srinalesti Mahanani \\ STIKES RS. Baptis Kediri Jl. Mayjend. Panjaitan No. 3B Kediri \\ Email: yulsiskawati@gmail.com
}

\begin{abstract}
ABSTRAK
Perkembangan motorik merupakan perkembangan Kontrol pergerakan badan melalui koordinasi aktivitas saraf pusat, saraf tepi, dan otot. Kontrol pergerakan ini muncul dari perkembangan refleks-refleks yang dimulai sejak lahir. Kemampuan gerak dalam keterampilan gerak dasar (fundamental motor skill) menggambarkan derajat penguasaan keterampilan dalam menggunakan jari-jari tangan, koordinasi mata-tangan dan mata-kaki, tempo keseimbangan, serta persepsi visual. Objek dalam penelitian ini adalah untuk mengamati perkembangan motorik anak usia prasekolah di Posyandu Balita Mawar dan Kenanga Kelurahan Bangsal Kota Kediri. Desain penelitian ini menggunakan Deskriptif. Populasi penelitian yaitu semua anak usia prasekolah (4-5 tahun) di Posyandu Balita Mawar dan Kenanga Kelurahan Bangsal Kota Kediri sejumlah 38 anak dengan sampel 34 responden dengan menggunakan teknik purposive sampling. Variabel tunggal yaitu perkembangan motorik anak usia prasekolah. Pengumpulan data menggunakan lembar observasi dianalisis menggunakan distribusi frekuensi. Hasil penelitian menunjukkan bahwa perkembangan motorik kasar menunjukkan sebagian besar responden memiliki skor tinggi menunjukkan performa atau keterampilan bagus yaitu sejumlah 32 responden $(94,1 \%)$, sedangkan perkembangan motorik halus menunjukkan lebih dari 50\% yang memiliki skor rendah menunjukkan performa atau keterampilan kurang bagus yaitu sejumlah 18 responden $(52,9 \%)$. Simpulan dalam penelitian ini adalah perkembangan motorik anak usia prasekolah di Posyandu Balita Mawar dan Kenanga Kelurahan Bangsal Kota Kediri adalah kategori performa atau keterampilan bagus.
\end{abstract}

\section{Kata kunci : Anak prasekolah, perkembangan motorik, Posyandu}

\begin{abstract}
Motoric development is the development of control of body movement through the coordination of central nervous activity, peripheral nerves, and muscles. This movement control arises from the development of reflexes that begin at birth. Motion ability in basic motion skills (fundamental motor skills) describes the degree of mastery of skills in using the fingers, eye-hand coordination and eye-foot, balance tempo, and visual perception. The object of this research is to observe motor development of preschool children at Posyandu Balita Mawar and Kenanga Kelurahan Bangsal Kediri. Design in this research using descriptive research. The population in this research is all children of preschool age (4-5 years) in Posyandu Balita Mawar and Kenanga Kelurahan Bangsal Kediri is 38
\end{abstract}


children. The sample is 34 respondents with purposive sampling tehcnique. The independent variable is motoric development of preschool children. Data collection using observation sheets were analyzed using frequency distribution analysis. The result of the research shows that the motoric development shows that most of the respondents have high score showing good performance/skill that is 32 respondents $(94,1 \%)$, whereas the development of fine motor show that more than 50\% have low score shows the performance or skill a total of 18 respondents (52.9\%). Conclusion in this research is motor development of preschool age children in Posyandu Balita Mawar and Kenanga Kelurahan Bangsal Kediri is good performance or skill category.

\section{Keywords: children preschool, motoric development, Posyandu}

\section{Pendahuluan}

Secara alamiah, setiap individu hidup akan melalui tahapan pertumbuhan dan perkembangan, yaitu sejak masa embrio sampai akhir hayatnya mengalami perubahan ke arah peningkatan baik secara ukuran maupun secara perkembangan. Salah satu perkembangan anak adalah perkembangan fisik, yang meliputi empat aspek yaitu system saraf yang mempengaruhi kecerdasan dan emosi, otot-otot yang mempengaruhi perkembangan kekuatan dan kemampuan motorik, kelenjar endokrin yang memunculkan pola-pola tingkah baru dan struktur fisik atau tubuh (Jahja, 2015). Ada banyak hal yang masih belum diketahui oleh para orangtua, yaitu tingkat pertumbuhan dan perkembangan anaknya. Setiap orangtua akan mengharapkan anaknya tumbuh dan berkembang secara sempurna tanpa mengalami hambatan apapun. Namun banyak faktor yang dapat berpengaruh terhadap proses pertumbuhan dan perkembangan anak tersebut dimana ada sebagian anak yang tidak selamanya tahapan tumbuh kembangnya sesuai dengan yang diinginkan orangtua (Riyadi, 2013). Berdasarkan hasil pra penelitian yang dilakukan pada tanggal 18 Desember 2017 sampai tanggal 24 Desember 2017 di Posyandu Balita Mawar dan Kenanga Kelurahan Bangsal Kota Kediri, didapatkan jenis aktivitas bermain anak terbanyak adalah menggambar dan menulis. Ada beberapa anak usia prasekolah aktivitas bermainnya tidak sesuai dengan tahap perkembangannya. Sesuai dengan teori dari Bakhtiar (2015), perkembangan motorik kasar anak prasekolah usia 3-4 tahun berjalan dengan $80 \%$ langkah orang dewasa, berlari 1/3 kecepatan orang dewasa, melempar dan menangkap bola besar, tetapi lengan masih kaku. Sedangkan perkembangan motorik halusnya yaitu mengancingkan baju, meniru bentuk sederhana, membuat gambar sederhana.

Menurut UNICEF tahun 2011 didapat data masih tingginya angka kejadian gangguan pertumbuhan dan perkembangan pada anak usia balita khususnya gangguan perkembangan motorik didapatkan $(27,5 \%)$ atau 3 juta anak mengalami gangguan. Pada tahun 2010 gangguan pertumbuhan dan perkembangan pada anak di Indonesia mencapai $35,7 \%$ dan tergolong dalam masalah kesehatan masyarakat yang tinggi menurut acuan WHO karena masih diatas 30\% (Riskesdas, 2010). Menurut hasil penelitian Ariyana (2009) Pada perkembangan motorik halus anak usia 45 tahun, motorik halus anak yang normal $75,4 \%$ dan perkembangan motorik halus anak yang abnormal 24,6\%. Data hasil pra penelitian pada tanggal 18 Desember 2017 sampai tanggal 24 Desember 2017 di Posyandu Balita Mawar dan Kenanga Kelurahan Bangsal Kota Kediri, anak prasekolah usia 4-5 tahun sejumlah 38 anak. Dari 6 anak saat dilakukan pra penelitian, didapatkan 4 anak $(66,67 \%)$ 
jenis aktivitas bermain tidak sesuai dengan tahap perkembangannya. Sedangkan 2 anak $(33,33 \%)$ jenis aktivitas bermain sudah sesuai dengan tahap perkembangannya.

Pada pertumbuhan masa pra sekolah pada anak pertumbuhan fisik khususnya berat badan mengalami kenaikan rata-rata per tahunnya adalah 2 $\mathrm{Kg}$, kelihatan kurus akan tetapi aktivitas motorik tinggi, di mana sistem tubuh sudah mencapai kematangan seperti berjalan, melompat, dan lain-lain (Hidayat, 2008). Perkembangan motorik merupakan perkembangan kontrol pergerakan badan melalui koordinasi aktivitas saraf pusat, saraf tepi, dan otot.Kontrol pergerakan ini muncul dari perkembangan refleks-refleks yang dimulai sejak lahir. Anak menjadi tidak berdaya sampai perkembangan ini muncul (Soetjiningsih, 2013). Menurut Riyadi (2013), tumbuh kembang prasekolah (4-5 tahun), meliputi pertumbuhan dan perkembangan motorik kasar, motorik halus, fisik, dan sosial emosional. Perkembangan motorik kasar, antara lain meliputi berjalan berjinjit, melompat, melompat dengan satu kaki, menangkap bola dan melemparnya dari atas kepala, berjalan mundur sambil berjinjit, sudah dapat menangkap dan melempar bola dengan baik, sudah dapat melompat dengan kaki secara bergantian. Perkembangan motorik halus, antara lain meliputi sudah bisa menggunakan gunting dengan lancar, sudah bias menggambar kotak, menggambar garis vertical maupun horizontal, belajar membuka dan memasang kancing baju, menulis dengan angka-angka, menulis dengan huruf, menulis dengan kata-kata, belajar menulis nama, belajar mengikat tali sepatu.

Sebagian besar waktu anak-anak akan dihabiskan untuk melakukan aktivitas motorik, seperti berlari, melompat, melempar dan menangkap (Santrock, 2011). Dunia anak tidak bisa dipisahkan dengan dunia bermain.Anak yang lebih banyak mendapat stimulasi cenderung lebih cepat berkembang. Kurangnya stimulasi dapat menyebabkan penyimpangan tumbuh kembang bahkan gangguan yang bersifat menetap (Sulistyawati, 2014). Faktor lingkungan serta kepribadian anak juga dapat mempengaruhi keterlambatan dalam perkembangan motorik. Anak yang tidak mempunyai kesempatan belajar seperti sering digendong atau diletakkan di baby walker dapat mengalami keterlambatan dalam mencapai kemampuan motorik (Adriana, 2011). Gerak dasar (motorik) merupakan dasar untuk mempelajari dan mengembangkan berbagai keterampilan teknik dalam berolahraga dan aktivitas fisik seumur hidup. Dengan demikian, jika kompetensi gerak dasar anak tidak dikembangkan, mereka tidak berhasil menggunakan berbagai keterampilan olahraga dan permainan pada usia kanakkanak dan remaja mereka. Selanjutnya, hal inilah yang menjadikan banyak anakanak dan remaja tidak memilih, berminat untuk ikut serta dan berpartisipasi pada berbagai macam kegiatan yang membutuhkan keterampilan fisik dalam permainan dan olahraga (Bakhtiar, 2015). Konsep dasar tumbuh kembang anak perlu dipahami oleh setiap tenaga medis dalam upaya mengoptimalkan tumbuh kembang anak (Soetjiningsih, 2013). Setiap anak perlu mendapat stimulasi rutin secara dini dan terus menerus pada setiap kesempatan. Stimulasi perkembangan anak adalah kegiatan merangsang kemampuan dasar anak usia 0-6 tahun agar berkembang secara optimal. Oleh karena itu, mengupayakan anak untuk berinteraksi dengan lingkungan sekitar merupakan salah satu kegiatan untuk stimulasi tumbuh kembang (Sulistyawati, 2014). Untuk mendukung perkembangan motorik halus anak, salah satunya dengan bermain karena berguna untuk mengembangkan koordinasi motorik (motorik kasar dan motorik halus) serta kemampuan mengontrol emosi (Adriana, 2011). Tujuan dari penelitian ini untuk menggambarkan perkembangan motorik anak usia prasekolah di Posyandu Balita Mawar dan Kenanga Kelurahan Bangsal Kota Kediri. 


\section{Metodologi Penelitian}

Desain penelitian yang digunakan pada penelitian ini adalah Deskriptif. Populasi pada penelitian ini adalah semua anak usia prasekolah (4-5 tahun) di Posyandu Balita Mawar dan Kenanga KelurahanBangsal Kota Kediri. Subyek dalam penelitian ini adalah anak usia prasekolah di Posyandu Balita Mawar dan Kenanga Kelurahan Bangsal Kota Kediri yang memenuhi criteria inklusi sebanyak 34 anak dengan menggunakan teknik purposive sampling. Pengambilan data menggunakan lembar observasi. Analisis data menggunakan distribusi frekuensi.

\section{Hasil Penelitian}

Tabel 1. Distribusi Frekuensi Karakteristik Perkembangan Motorik Anak Usia Prasekolah di Posyandu Balita Mawar dan Kenanga Kelurahan Bangsal Kota Kediri yang dilakukan pada tanggal 24 Maret 2018 s.d 27 Maret $2018(\mathrm{n}=34)$

\begin{tabular}{lcc}
\multicolumn{1}{c}{ Karakteristik Perkembangan Motorik } & \multicolumn{2}{c}{} \\
\hline Performa/keterampilan bagus & 28 & 82,4 \\
Performa/keterampilan kurang bagus & 6 & 17,6 \\
\hline Jumlah & 34 & 100 \\
\hline
\end{tabular}

\begin{tabular}{lllllllll}
\multicolumn{2}{c}{ Berdasarkan } & tabel 1 & dapat & & responden & $(82,4 \%)$ & dan sejumlah & 6 \\
diketahui & bahwa & sebagian & besar & & responden $(17,6 \%)$ & memiliki performa \\
responden & memiliki performa & atau & & atau keterampilan & kurang bagus.
\end{tabular}
keterampilan bagus yaitu sejumlah 28

Tabel 2. Distribusi Frekuensi Karakteristik Perkembangan Motorik Anak Usia Prasekolah di Posyandu Balita Mawar dan Kenanga Kelurahan Bangsal Kota Kediri yang dilakukan pada tanggal 24 Maret 2018 s.d 27 Maret $2018(n=34)$

\begin{tabular}{lcccccc}
\hline \multirow{2}{*}{$\begin{array}{c}\text { Perkembangan } \\
\text { Motorik }\end{array}$} & \multicolumn{2}{c}{$\begin{array}{c}\text { Performa/ } \\
\text { keterampilan bagus }\end{array}$} & $\begin{array}{c}\text { Performa/ keterampilan } \\
\text { kurang bagus }\end{array}$ & \multicolumn{2}{c}{ Jumlah } \\
\cline { 2 - 7 } & $\sum$ & $\mathbf{\%}$ & $\sum$ & $\mathbf{\%}$ & $\sum$ & \% \\
\hline Kasar & 32 & 94,1 & 2 & 5,9 & 34 & 100 \\
Halus & 17 & 50,0 & 17 & 50,0 & 34 & 100 \\
\hline
\end{tabular}

Berdasarkan tabel 2 dapat dikatakan bahwa pada perkembangan motorik kasar mayoritas responden memiliki performa/keterampilan bagus yaitu sejumlah 32 responden $(94,1 \%)$. Perkembangan motorik halus memiliki performa/keterampilan kurang bagus yaitu sejumlah 17 responden $(50,0 \%)$.

\section{Pembahasan}

\section{Perkembangan Motorik Anak Usia Prasekolah}

Berdasarkan hasil penelitian tentang gambaran perkembangan motorik anak usia prasekolah di Posyandu Balita Mawar dan Kenanga Kelurahan Bangsal Kota Kediri didapatkan dari 34 responden, sebagian besar responden memiliki performa atau keterampilan bagus yaitu sejumlah 28 responden $(82,4 \%)$. 
Perkembangan motorik pada anak mencerminkan mielinisasi pada traktus kortikospinal, pyramidal dan kortikobulbar. Perkembangan motorik terjadi secara sefalokaudal dan psoksimodistal. Pergerakan pertama dimulai dari kepala, kemudianbahu, badan, dan pinggul. Perkembangan motorik dibagi menjadi dua yaitu motorik kasar dan motori khalus. Perkembangan motorik kasar merupakan aspek yang berhubungan dengan perkembangan lokomosi (gerak) dan postur (posisi tubuh). Perkembangan motorik halus merupakan koordinasi halus pada otototot kecil yang memainkan suatu peran utama. Suatu keterampilan menulis huruf "a" merupakan serangkaian beratus-ratus koordinasi saraf otot. Pergerakan terampil adalah proses yang kompleks (Soetjiningsih, 2013).

Menurut Bakhtiar (2015), perkembangan motorik anak usia prasekolah (4-5 tahun) yaitu meliputi keterampilan motorik kasar dan halus. Perkembangan motorik kasar meliputi aktivitas berjalan berjinjit, berjalan mundur sambil berjinjit, melompat, melompat dengan satu kaki, menangkap bola dan melemparnya dari atas kepala, sudah dapat menangkap dan melempar bola dengan baik, sudah dapat melompat dengan kaki secara bergantian. Keterampilan motorik halus meliputi aktivitas sudah bisa menggunakan gunting dengan lancar, sudah bisa menggambar kotak, garis vertikal maupun horisontal, belajar membuka dan memasang kancing baju, menulis dengan angka-angka, menulis dengan huruf, menulis dengan kata-kata, belajar menulis nama, dan belajar mengikat tali sepatu.

Perkembangan merupakan proses yang tidak pernah berhenti (never ending process). Setiap aspek perkembangan individu baik fisik, emosi, intelegensi ini saling mempengaruhi. Setiap individu yang normal akan mengalami tahapan/fase perkembangan. Berarti bahwa dalam menjalani hidupnya yang normal dan berusia panjang individu akan mengalami fase-fase perkembangan dari bayi, kanak-kanak, remaja, dewasa, dan masa tua. Perkembangan itu mengikuti pola atau arah tertentu, dimana hasil perkembangan dari tahap sebelumnya merupakan syarat bagi perkembangan selanjutnya. Anak usia prasekolah berada pada masa kanakkanak awal. Periode ini berasal sejak anak dapat bergerak sambil berdiri sampai mereka masuk sekolah, dicirikan dengan aktivitas yang tinggi dan penemuan-penemuan. Periode ini merupakan perkembangan fisik dan kepribadian yang besar. Perkembangan motorik yang berlangsung terus menerus. Anak-anak pada usia ini membutuhkan bahasa dan hubungan sosial yang lebih luas, mempelajari standar peran, memperoleh kontrol dan penguasaan diri, semakin menyadari sifat ketergantungan dan kemandirian, dan mulai membentuk konsep diri (Oktiawati, dkk, 2017).

Hasil penelitian ini menunjukkan sebagian besar responden memiliki performa atau keterampilan bagus. Berdasarkan hal ini penguasaan keterampilan yang dimiliki anak, pada saat diarahkan untuk melakukan beberapa aktivitas anak melakukannya dengan baik dan berhasil. Masa kanakkanak merupakan masa bermain sepanjang hari, anak menjadi aktif dan mendapat pengalaman-pengalaman baru dengan lingkungan sekitarnya (keluarga, teman sebaya, dan lain-lain). Data hasil crosstabulation antara usia responden dengan perkembangan motorik didapatkan 9 dari 11 responden yang berusia 4 tahun memiliki performa atau keterampilan bagus. Berdasarkan hal ini pada usia tersebut masa kanak-kanak awal yang juga merupakan awal masa anak cenderung aktif untuk beraktivitas dan meluaskan dunia kecil mereka dengan hal-hal baru yang mereka temui setiap harinya. Pada masa ini juga harus dioptimalkan pertumbuhan dan perkembangan anak sehingga pada masa atau periode berikutnya tidak terdapat hambatan pada pertumbuhan dan perkembangan anak.

Hasil penelitian menunjukkan perkembangan motorik anak usia 
prasekolah memiliki performa atau keterampilan bagus yaitu sejumlah 28 responden $(82,4 \%)$. Perkembangan masa awal anak-anak di mana anak-anak pra sekolah mengalami proses perkembangan secara bertahap. Melalui beberapa perkembangan, di antaranya fisik, kognitif, emosi, dan psikososial. Dari perkembangan ini anak mulai mengalami perubahan, contohnya dari segi fisik, bertambahnya tinggi dan berat badan anak; dari segi kognitif, adanya perubahan cara berpikir anak; dari segi emosi, sudah mulai dapat mengekspresikan rasa emosinya; sedangkan segi psikososial, anak dapat berhubungan atau bersosialisasi dengan lingkungannya (Jahja, 2015). Berdasarkan hal ini perkembangan motorik anak usia prasekolah sudah berkembang dengan baik sesuai dengan periode perkembangannya yaitu pada usia prasekolah perkembangan motorik berlangsung secara terus menerus ditandai dengan peningkatan aktivitas yang tinggi dan pengalaman atau penemuan hal-hal baru. Dari hasil cross tabulation antara usia responden dengan perkembangan motorik didapatkan mayoritas anak prasekolah yang berhasil melakukan adalah anak usia 4 tahun, dikarenakan pada usia ini merupakan usia awal kanak-kanak dalam aktif beraktivitas dan bereksplorasi terhadap lingkungannya sehingga anak-anak aktif beraktivitas seperti aktivitas berjalan berjinjit, berjalan mundur sambil berjinjit, menangkap dan melempar bola, melompat, menggunakan gunting, menggambar, membuka dan memasang kancing baju.

Menurut Riyadi (2013), tumbuh kembang prasekolah, meliputi pertumbuhan dan perkembangan motorik kasar, motorik halus, fisik, dan social emosional. Perkembangan motorik kasar seperti berjalan mundur sambil berjinjit, sudah dapat menangkap dan melempar bola dengan baik, sudah dapat melompat dengan kaki secara bergantian. Perkembangan motorik halus seperti menulis dengan angka-angka, menulis dengan huruf, menulis dengan kata-kata, belajar menulis nama, belajar mengikat tali sepatu. Pada usia ini waktu bermain sendiri mulai berkurang, sering berkumpul dengan teman sebaya, interaksi social selama bermain meningkat, sudah siap untuk menggunakan alat-alat bermain. Berdasarkan hal tersebut dengan adanya kesiapan anak untuk berinteraksi atau bermain dengan sekitarnya akan meningkatkan perkembangan fisik anak, yang juga ditandai dengan berkembangnya kemampuan motorik anak. Selain itu hal yang berpengaruh terhadap perkembangan motorik anak dengan batuan dari orangtua, terutama yang orangtua yang tidak bekerja/ibu rumah tangga dan fokus mengurus anak. Anak-anak akan mendapat perhatian dan pengawasan yang lebih daripada anak dengan orangtua yang bekerja. Saat orangtua bekerja anak akan diasuh oleh nenek atau anggota keluarga lain dan kemungkinan tidak mendapatkan pengajaran tentang belajar sambil bermain yang dapat meningkatkan kemampuan/keterampilan anak dalam melakukan suatu hal.

Hasil penelitian pada perkembangan motorik kasar menunjukkan performa atau keterampilan bagus yaitu sejumlah 32 responden $(94,1 \%)$. Perkembangan adalah pola perubahan yang dimulai sejak masa konsepsi dan berlanjut sepanjang kehidupan (Santrock, 2011). Perkembangan keterampilan motorik atau yang biasa disebut juga dengan perkembangan gerak dasar adalah perkembangan untuk berbagai keterampilan teknik dalam berolahraga dan beraktivitas fisik seumur hidup. Keterampilan motorik juga sangat penting untuk dilatih sejak usia dini karena pada usia ini merupakan awal masa anak untuk aktif beraktivitas dan berinteraksi dengan lingkungan sekitarnya. Pada masa prasekolah kemampuan gerak mulai muncul dan berkembang, pola gerak mereka juga dipengaruhi oleh pertumbuhan fisik dan pengalaman gerak yang dimiliki. Kemampuan dasar anak juga perlu 
dilakukan stimulasi perkembangan secara rutin agar perkembangan anak dapat dioptimalkan dengan baik. Pada Posyandu Balita Mawar didapatkan perkembangan motorik kasarnya mayoritas responden memiliki performaatau keterampilan bagus yaitu sejumlah 19 responden $(90,5 \%)$ dari total responden sejumlah 21 responden. Adapun pada Posyandu Balita Kenanga didapatkan perkembangan motorik kasarnya mayoritas responden memiliki performa/keterampilan bagus yaitu sejumlah 13 responden $(100 \%)$. Hal ini dibuktikan dengan responden yang berhasil melakukan aktivitas sesuai dengan arahan yang diberikan dan juga responden sering melakukan aktivitas tersebut dalam kehidupan sehari-hari seperti berjalan berjinjit, melompat, menangkap dan melempar bola.

$$
\text { Hasil penelitian pada }
$$

perkembangan motorik halus menunjukkan performa atau keterampilan kurang bagus yaitu sejumlah 17 responden $(50 \%)$. Hal ini dibuktikan bahwa lebih dari 50\% di Posyandu Balita Mawar memiliki performa atau keterampilan kurang bagus yaitu sejumlah 11 responden $(52,4 \%)$ dan di Posyandu Balita Kenanga memiliki performa/keterampilan kurang bagus yaitu sejumlah 6 responden $(46,2 \%)$. Usia prasekolah, mengalami perkembangan otot-otot besar terlebih dahulu daripada otot-otot kecil atau halus, sehingga anak masih sering mengalami kesulitan apabila harus memfokuskan pandangannya pada objekobjek yang kecil ukurannya, itulah sebabnya koordinasi tangan dan matanya masih kurang sempurna (Oktiawati, dkk, 2017). Pendapat ini sejalan dengan Corbin (1980) dalam Bakhtiar (2015), bahwa masa anak-anak adalah masa yang tepat untuk mempelajari keterampilan gerak dasar, setelah masa tersebut adalah masa menghaluskan keterampilan gerak dasar, sehingga ini menurutnya adalah masa yang kritis untuk mempelajari keterampilan gerak dasar. Perkembangan keterampilan gerak dengan mempelajari berbagai keterampilan dan mempelajari konsep tentang gerak, sehingga anakanak perlu di didik dan dikembangkan keseluruhan potensinya, tidak hanya intelektualnya, tapi juga sikap, moral, fisik, dan motoriknya. Hal ini juga didasari karena banyaknya anak yang di Posyandu Balita Mawar dan Kenanga yang belum sekolah, yang belum mendapatkan pendidikan tentang aktivitas-aktivitas yang terkait motorik halus seperti menulis dan menggambar. Berdasarkan hal ini berarti responden tidak bisa mencapai aspek perkembangan yang optimal dalam keterampilan motorik halus, yaitu aspek yang berhubungan dengan kemampuan anak melakukan gerakan yang melibatkan bagian-bagian tubuh tertentu dan dilakukan oleh otot-otot kecil, tetapi memerlukan koordinasi yang cermat seperti mengamati sesuatu, menjimpit, menulis, dan lain-lain. Selain itu, faktor dari lingkungan keluarga juga berpengaruh terhadap perkembangan motorik anak. Orangtua yang aktif untuk mengajari anak dalam memegang alat tulis, menghafal objek tertentu, akan membuat anak lebih aktif dalam belajar pula. Anak juga akan cenderung lebih aktif dalam beraktifitas, terutama dalam menggunakan koordinasi mata-tangan. Sebagai contoh saat anak perlu keterampilan menggunting untuk mengembangkan keterampilan motorik halus. Selain itu, keterampilan menulis juga belum berhasil dilakukan karena pada usia ini anak masih pada tahap belajar menulis dan masih belajar mengikat tali sepatu sehingga padasaat dilakukan observasi atau pengamatan didapatkan hasilyang kurang bagus.

Hasil penelitian menunjukkan pada usia 4 hingga 4,2 tahun, responden sudah berhasil melakukan aktivitas motorik kasar seperti berjalan berjinjit, berjalan mundur sambil berjinjit serta menangkap dan melempar bola. Usia awal anak-anak merupakan awal mulainya keaktifan anak untuk beraktivitas dengan lingkungan sekitarnya. Pada usia ini anak juga senang berpetualang atau mencari pengalaman-pengalaman baru dari sekitarnya dan mulai menekuni hal 
tersebut (Santrock, 2011). Menurut orangtua responden bahwa anak sering menghabiskan sebagian besar waktunya untuk bermain, dalam hal ini juga termasuk dalam aktivitas motorik kasar anak seperti berlari, melompat, melempar dan menangkap. Aktivitas tersebut juga bisa menjadi dasar keterampilan lanjutan pada perkembangan anak sehingga orangtua atau pendidik bisa mengarahkan dan berinteraksi dengan anak agar kemajuan dari perkembangan motoriknya lebih efektif dan terkoordinasi dengan baik. Aktivitas motorik halus yang berhasil dilakukan pada usia ini yaitu aktivitas membuka dan memasang kancing baju, hal ini dikarenakan anak sudah belajar bagaimana cara membuka dan memasang kembali kancing bajunya seperti yang ia tiru dari yang orangtua lakukan.

Berdasarkan pada usia 4,3 tahun dan 4,4 tahun kemajuan perkembangan motorik sudah lebih berkembang dari sebelumnya, dengan anak sudah berhasil melakukan aktivitas motorik kasar seperti melompat dengan satu kaki dan pada aktivitas motorik halusnya seperti bisa menggunakan gunting dan juga menggambar. Periode kanak-kanak awal menunjukkan perkembangan motorik yang lebih lanjut dan anak menunjukkan kemampuan aktivitas lebih banyak bergerak, mengembangkan rasa ingin tahu, dan eksplorasi terhadap benda yang ada di sekelilingnya. Keterampilan motorik, seperti berjalan, berlari, melompat menjadi semakin luwes, tetapi otot dan tulang belum begitu sempurna (Supartini, 2004). Perkembangan motorik halus (koordinasi otot-otot kecil) telah meningkat dari usia sebelumnya. Aktivitas motorik kasar sudah berkembang seperti mereka sudah bisa belajar menjaga keseimbangan tubuhnya dengan berjalan berjinjit, berjalan mundur sambil berjinjit, dan melompat dengan satu kaki, serta pada aktivitas motorik halusnya mereka bisa memegang dan menggunakan gunting, meskipun hasil yang didapat kurang sempurna tetapi anak sudah berusaha untuk melakukan aktivitas tersebut semampu mereka. Pada usia ini anak-anak juga bisa menggambar kotak dan garis tetapi dengan bentuk yang belum sempurna (tegak atau lurus). Berdasarkan hasil crosstabulation antara usia responden dengan perkembangan motorik didapatkan 4 dari 5 responden memiliki performa atau keterampilan bagus. Berdasarkan hal tersebut dengan adanya kesiapan anak untuk berinteraksi atau bermain dengan sekitarnya akan meningkatkan perkembangan fisik anak, yang juga ditandai dengan berkembangnya kemampuan motorik anak. Pertumbuhan dan perkembangan anak adalah hal yang penting yang harus diperhatikan oleh orangtua sehingga orangtua harus mengajarkan anak untuk belajar, seperti misalnya dalam hal memegang gunting, menulis dan menggambar tetapi dengan situasi bermain sehingga anak melakukannya tidak dengan terpaksa. Anak membutuhkan bantuan orang lain dalam menstimulasi perkembangannya. Selain itu hal yang berpengaruh terhadap perkembangan motorik anak dengan batuan dari orangtua, terutama yang tidak bekerja atau ibu rumah tangga dan fokus mengurus anak.

Hasil penelitian menunjukkan pada usia 4,7 tahun dan 4,9 tahun aktivitas motorik baik kasar maupun halus juga lebih berkembang dari usia sebelumnya. Selama tahun-tahun awal, anak-anak menghabiskan banyak waktu untuk berinteraksi dengan lingkungan melalui aktivitas gerakan seperti bergerak pelanpelan, merangkak, berjalan, melompat. Perkembangan erat hubungannya dengan maturasi sistem saraf (Bakhtiar, 2015). Perkembangan motorik mereka sudah lebih baik dengan berhasil dalam menjaga keseimbangan tubuh dalam aktivitas melompat dengan satu kaki dan melompat dengan kaki secara bergantian. Hal ini sejalan dengan pada usia ini aktivitas motorik kasar sudah lebih matang. Perkembangan motorik halus mereka juga meningkat yaitu seperti bisa menulis huruf dan angka tetapi hanya terbatas pada beberapa huruf atau angka. Berdasarkan hal ini beberapa anak sudah 
diajarkan oleh orangtua mereka dirumah dan berlatih untuk menulis angka dan huruf dengan meniru pada contoh gambar angka huruf yang ditempel di dinding rumah. Perkembangan motorik kasar dan motorik halus pada usia ini sudah sesuai dengan derajat penguasaan usia prasekolah, dibuktikan dengan anak sudah bisa menguasai beberapa aktivitas motorik kasar seperti melompat dengan satu kaki dan melompat dengan kaki secara bergantian, serta aktivitas motorik halus sudah bisa menguasai beberapa huruf dan angka yang perlu dilatih kembali supaya penguasaan pada keterampilan menulis dapat dioptimalkan pada usia ini.

Berdasarkan usia 4,10 tahun dan 4,11 tahun perkembangan motorik juga meningkat baik perkembangan motorik kasar maupun motorik halus. Misalnya pada usia ini mereka sudah berhasil menulis kata-kata dan belajar menulis nama mereka sendiri. Aktivitas motorik juga berkembang lebih baik dan matang pada usia ini, gerakan-gerakan dalam aktivitas mereka dapat dilakukan dengan arah maju dan mundur seperti berlatih keterampilan lokomotor (berlari, melompat, meluncur, melompat kecil, dan melompat tinggi). Anak-anak juga aktif berpartisipasi untuk melakukan arahan aktivitas yang diberikan oleh peneliti. Keberhasilan ini dikarenakan anak sering melakukan hal tersebut dirumah, baik dengan tuntunan dari orangtua maupun juga saat bermain dengan teman sebaya atau lingkungannya. Sesuai dengan yang dikemukakan oleh Ulrich (2000) dalam Bakhtiar (2015), pola gerakan yang sering diulang menghasilkan penguatan terhadap jalur saraf yang mendukung pola gerakan. Mereka telah memiliki penguasaan terhadap tubuhnya dan sangat menyukai kegiatan yang dilakukan sendiri. Hal ini membuktikan penguasaan pada keterampilan motorik kasar dan halus sudah lebih baik dari usia sebelumnya seperti pada aktivitas berjalan, melompat, menangkap dan melempar bola, menggunakan gunting dengan lancar, aktivitas menggambar dan menulis, serta pada usia ini juga anak dipersiapkan untuk memasuki jenjang pendidikan dasar seperti PAUD atau TK.

Menurut Pangrazi (2004) dalam Bakhtiar (2015) sangat penting mempelajari keterampilan gerak dasar pada usia dini karena apabila kurang diajarkan tentang keterampilan gerak dasar, anak akan mengalami berbagai hambatan atau kendala dalam mempelajari berbagai keterampilan gerak yang lebih sulit di kemudian hari, seperti mempelajari keterampilan teknik olahraga (sport skill) nantinya. Peran seperti lingkungan dan pengalaman individu menciptakan variabilitas dari perilaku. Anak bermain sesuai dengan kesukaan mereka, tetapi peran dari orangtua untuk mengajarkan hal-hal sesuai dengan tahap tumbuh kembang atau usia anak juga sangat penting guna mengoptimalkan tumbuh kembang anak. Menurut Corbin (1980) dalam Bakhtiar (2015), bahwa masa anak-anak adalah masa yang tepat untuk mempelajari keterampilan gerak dasar, setelah masa tersebut adalah masa menghaluskan keterampilan gerak dasar, sehingga ini menurutnya adalah masa yang kritis untuk mempelajari keterampilan gerak dasar. Perkembangan keterampilan gerak dengan mempelajari berbagai keterampilan dan mempelajari konsep tentang gerak, sehingga anak-anak perlu di didik dan dikembangkan keseluruhan potensinya, tidak hanya intelektualnya, tapi juga sikap, moral, fisik, dan motoriknya.

Pada anak yang berusia 5 hingga 5,2 tahun yaitu sejumlah 6 responden menunjukkan hasil sebagian besar responden memiliki performa atau keterampilan bagus yaitu sejumlah 5 responden. Perkembangan gerak dasar menurut Ulrich (2000) dalam Bakhtiar (2015), selama tahun-tahun sebelum memasuki sekolah dan masa sekolah dasar, kemampuan motorik (gerak) seorang anak mulai muncul dan berkembang. Perkembangan fisik merupakan dasar bagi kemajuan perkembangan berikutnya, memungkinkan anak untuk dapat lebih 
mengembangan keterampilan fisik dan eksplorasi terhadap lingkungannya dengan tanpa bantuan dari orangtuanya. Usia ini juga terjadinya pertumbuhan "myelinization" (lapisan putih, yaitu myelin) secara sempurna. Lapisan urat saraf ini membantu transmisi impulsimpuls saraf secara cepat, yang memungkinkan pengontrolan terhadap kegiatan-kegiatan motorik lebih seksama dan efisien. Rata-rata responden yang masih kurang bisa melakukan aktivitas melompat dengan satu kaki atau secara bergantian adalah anak perempuan. Anak perempuan biasanya jauh diatas anak laki-laki dalam hal keterampilan motorik halus, begitupun sebaliknya, anak lakilaki biasanya jauh diatas anak perempuan dalam hal keterampilan motorik kasar yang melibatkan banyaknya aktivitas otot (Santrock, 2011).

Pada usia 5 tahun, perkembangan motorik anak berkembang dengan baik, dibuktikan dengan keberhasilan melakukan aktivitas yang diarahkan oleh peneliti. Perkembangan motorik halus pada usia ini juga lebih matang dan meningkat daripada usia 4 tahun, semua anggota bagian tubuh dan koordinasi sudah menunjukkan kemajuan perkembangan yang baik. Pada usia ini anak-anak juga sudah disiapkan untuk memasuki jenjang pendidikan lanjutan yaitu PAUD dan beberapa responden sudah berpendidikan PAUD. Perkembangan motorik halus pada usia ini dibuktikkan dengan anak berhasil untuk menulis angka, huruf, kata-kata dan nama dengan baik, sudah bisa menggunakan gunting dengan lancar dengan mengikuti bentuk atau pola gambar pada kertas, bisa menggambar kotak dan garis, serta sudah bisa belajar untuk mengikat tali sepatu. Hasil crosstabulation antara usia responden dengan perkembangan motorik didapatkan 5 dari 6 responden memiliki performa atau keterampilan yang bagus yang dibuktikan dengan penguasaan keterampilan yang baik pada keterampilan motorik kasar dan motorik halus. Anak yang sudah bependidikan PAUD juga dilatih untuk bermain sambil belajar sehingga kemampuan anak semakin diasah dan dioptimalkan tahap tumbuh kembangnya pada usia ini terutama pada keterampilan gerak dasar (motorik). Dengan terarahnya stimulasi perkembangan yang diberikan secara rutin dan terus-menerus dapat meningkatkan perkembangan anak, yaitu dengan merangsang kemampuan gerak kasar, kemampuan gerak halus, kemampuan bicara, bahasa serta kemapuan sosialisasi dan kemandirian.

\section{Simpulan}

Perkembangan motorik anak usia prasekolah di Posyandu Balita Mawar dan Kenanga Kelurahan Bangsal Kota Kediri memiliki performa atau keterampilan bagus.

\section{Saran}

Dari hasil penelitian ini diharapkan dapat dijadikan masukan untuk kader posyandu serta memberikan motivasi orang tua untuk lebih memperhatikan dan memberikan aktivitas atau latihan yang dapat meningkatkan perkembangan anak dengan mengadakan kegiatan atau pembelajaran untuk meningkatkan aktivitas anak sehingga perkembangan anak dapat dioptimalkan.

\section{Daftar Pustaka}

Adriana, Dian. (2011). Tumbuh Kembang dan Terapi Bermain pada Anak. Jakarta: Salemba Medika

Ariana, Desi R. (2009). Hubungan Pengetahuan Ibu Tentang Perkembangan Anak Dengan Perkembangan Motorik Kasar dan Motorik Halus Anak Usia 4-5 Tahun di TK Aisyiyah Khustanul Athfal 7 Semarang.Jurnal 
Keperawatan Vol. 2 No. 2 Maret 2009: 11-20.

Badan Penelitian dan Pengembangan Kesehatan. (2010). Riset Kesehatan Dasar Riskesdas 2010. Diakses dari http://www.depkes.go.id/riskesdas 2010.pdf pada tanggal 18 Desember 2017.

Bakhtiar, Syahrial (2015). Merancang Pembelajaran Gerak Dasar Anak. Padang: UNP Press.

Hidayat, A. Aziz Alimul. ( 2008). Pengantar Ilmu Keperawatan Anak. Jakarta: Salemba Medika

Jahja, Yudrik. (2015). Psikologi Perkembangan. Prenamedia Group: Jakarta

Oktiawati, Anisa, dkk (2017). Teori dan Konsep Keperawatan Pediatrik. Jakarta: CV. Trans Info Media

Riyadi. (2013). Asuhan Keperawatan pada Anak. Yogyakarta: Graha Ilmu

Santrock, John W. (2011). Masa Perkembangan Anak. Jakarta: Salemba Medika

Soetjiningsih. (2013). Tumbuh Kembang Anak Edisi 2. Jakarta: EGC

Sulistyawati, Ari. (2015). Deteksi Tumbuh Kembang Anak. Jakarta: Salemba Medika. 